\title{
Biarkanlah Perempuan dengan HIV/AIDS Berbicara! Teologi Interkultural Feminis Poskolonial dalam Ketidakadilan Gender
}

\author{
Paulus Eko Kristianto* \\ Sekolah Tinggi Filsafat Driyarkara, Jakarta, Indonesia \\ Email: paulusekokristianto@gmail.com
}

\begin{abstract}
This article discusses feminist intercultural theological (mission) models in the context of gender injustice experienced by women living with HIV/AIDS. Through library research, the authors find that the right model is to provide space for those who talk integrated with service. Service is not only for God, but for each other in a concrete way, including realizing gender justice for women with HIV/AIDS.
\end{abstract}

Keywords: Feminist; gender justice; intercultural; theology; woman.

\begin{abstract}
Abstrak
Artikel ini membahas model berteologi (misi) interkultural feminis dalam konteks ketidakadilan gender yang dialami perempuan pengidap HIV/AIDS. Melalui penelitian pustaka, penulis menemukan bahwa model yang tepat ialah memberikan ruang bagi mereka berbicara yang terintegrasi dengan pelayanan. Pelayanan tidak hanya kepada Tuhan, melainkan sesama secara konkrit, termasuk mewujudkan keadilan gender bagi perempuan pengidap HIV/AIDS.
\end{abstract}

Kata Kunci: feminis; interkultural; keadilan gender; perempuan; teologi.

\section{PENDAHULUAN}

Kini, komunitas iman tidak boleh hanya sekedar berfokus pada persoalan ritual atau ibadah semata. Sebagai komunitas iman kontekstual, ia harus diajak masuk dengan keberanian menghadapi konteks nyata. Salah satunya berkenaan dengan ketidakadilan gender yang dialami perempuan dengan HIV/AIDS. Guna menghadapi masalah ini, komunitas iman harus memiliki persiapan dan strategi melalui fondasi filosofis yang matang. Bagaimana caranya? Penelitian ini mencoba mencarinya lebih jauh dan dalam melalui refleksi filosofis.

Tidak banyak diskusi dan penelitian terkait dengan agama dan penderita HIV/AIDS. Hal ini bertolak belakang dengan peran penganut agama yang merupakan struktur masyarakat yang diharapkan memainkan peran penting dalam layanan HIV berbasis (Ndlovu-Teijema et al., 2021). Publikasi ilmiah terkini tentang iman dan kolaborasi kesehatan sebagian besar terdiri dari tinjauan umum dan studi observasional (Olivier \& Wodon, 2012). Penelitian dari Ziersch dkk. (2021) mengungkapkan bahwa pendetita HIV/AIDS adalah sangat terstigma dalam komunitas etnis yang beragam karena takut penilaian moral dan isolasi sosial, dan dialami di persimpangan gender, orientasi seksual, agama, dan budaya. Atas dasar tersebut pengaruh agama dan sistem kepercayaan secara luas diakui sebagai faktor penting dalam memahami persepsi risiko kesehatan dan mitos dalam perjuangan umum melawan pandemi HIV (Mapingure et al., 2021). Sebuah penelitian di Inggris mengungkapkan menjadi lebih religius dan sering menghadiri pertemuan keagamaan dikaitkan dengan kemungkinan yang lebih rendah untuk didiagnosis dengan untuk terkena HIV/AIDS (Awaworyi Churchill, Appau, \& Ocloo, 2021). 
Khazanah Theologia, Vol. 3 No. 3 (2021): 147-160

Biarkanlah Perempuan dengan HIV/AIDS Berbicara! Teologi Interkultural Feminis Poskolonial dalam Ketidakadilan Gender

Paulus Eko Kristianto

Dari berbagai penelitian tersebut belum ada yang menyelidiki cara berteologi bagi perempuan penderita HIV/AIDS yang mengalami ketidakadilan. Artikel ini mencoba menjawab pertanyaan krusial "Bagaimana model berteologi (misi) interkultural feminis dalam konteks ketidakadilan gender yang dialami perempuan pengidap HIV/AIDS?" Pertanyaan tersebut menjadi pengarah dalam meneliti lebih jauh berbagai kenyataan ketidakadilan gender dan terobosan mengatasinya dengan menggunakan metode penelitian pustaka terhadap buku dan jurnal yang relevan. Dalam prosesnya, penulis memaparkan berbagai bagian berikut; subalternitas perempuan dengan HIV (Human Immunodefficiency Virus) atau AIDS (Acquired Immuno Defficiency Syndrome), belajar dari Gayatri C. Spivak: perempuan membebaskan diri dan berbicara, menelisik teologi feminis poskolonial, berteologi (misi) interkultural.

\section{HASIL DAN PEMBAHASAN}

\section{Subalternitas Perempuan dengan HIV/AIDS}

Persoalan HIV/AIDS sebenarnya tidak bisa dikatakan terlepas dari isu gender. Data United Nations Programme on HIV/AIDS (UNAIDS) pada tahun 2002 menunjukkan perempuan bisa diperkirakan sebagai kelompok yang paling tinggi terinfeksi HIV/AIDS di seluruh dunia. Bahkan, infeksi HIV/AIDS di kalangan perempuan mengalami peningkatan sangat pesat. Pada tahun 2005, pengidap HIV/AIDS di Indonesia diperkirakan mencapai satu juta orang dengan prevalensi 0,53 kasus per 100.000 penduduk. Rasio antara laki-laki dan perempuan yakni 7: 2. Meski demikian, perempuan merupakan kelompok yang rentan terinfeksi HIV/AIDS (Arifin, 2005).

Spesifikasi tersebut dikarenakan perempuan memiliki kerentanan faktor biologis, sosial kultural, dan ekonomi. Faktor biologis dinyatakan karena vagina perempuan memiliki lapisan lipatan-lipatan berongga tipis yang lembut dan mudah terluka sehingga air mani bisa bertahan lebih lama dalam rongga vagina. Oleh karenanya jika terjadi perkosaan yang dapat melukai vagina, kemungkinan perempuan terinfeksi dua sampai empat kali lebih besar. Dari sisi sosial kultural, perempuan sedikit sukar bila menolak hubungan seksual dengan suaminya. Meskipun kerap kali, ia tidak tahu apakah suaminya mengidap HIV/ AIDS atau tidak. Akibatnya, jika pasangan tersebut sudah terinfeksi HIV, maka ia menjadi rentan tertular. Sisi sosial kultural turut terintegrasi dengan ekonomi. Hal ini dialami bila perempuan telah tergantung secara ekonomi kepada laki-laki. Maka, ia bisa semakin sulit memiliki sikap posisi tawar untuk menolak hubungan seksual dengan pasangannya.

Ketimpangan gender yang dikonstruksi budaya patriarkhi membuat laki-laki tidak perlu berkomunikasi dengan perempuan sebagai pasangan seksualnya. Maka, perempuan dimungkinkan tidak berdaya untuk melakukan komunikasi seksual, termasuk negosiasi menggunakan kondom dalam hubungan seksual. Apalagi bila perempuan merasa tergantung penuh kondisi ekonominya pada pasangannya, maka ia semakin berada dalam posisi lemah. Oleh karenanya, Ikatan Perempuan Positif Indonesia (IPPI) sebagai jaringan yang terbentuk dari hasil Lokakarya Peningkatan Keterampilan Perempuan dalam Penanggulangan HIV/ AIDS merumuskan permasalahan dan kebutuhan perempuan positif secara umum. Secara lengkap, rumusan tersebut tertuang pada tabel 1 (Subiyantoro, 2005). 
Khazanah Theologia, Vol. 3 No. 3 (2021): 147-160

Biarkanlah Perempuan dengan HIV/AIDS Berbicara! Teologi Interkultural Feminis Poskolonial dalam Ketidakadilan Gender

Paulus Eko Kristianto

Tabel 1. Permasalahan dan Kebutuhan Perempuan dengan HIV/AIDS

\begin{tabular}{|c|c|}
\hline Permasalahan & Kebutuhan \\
\hline 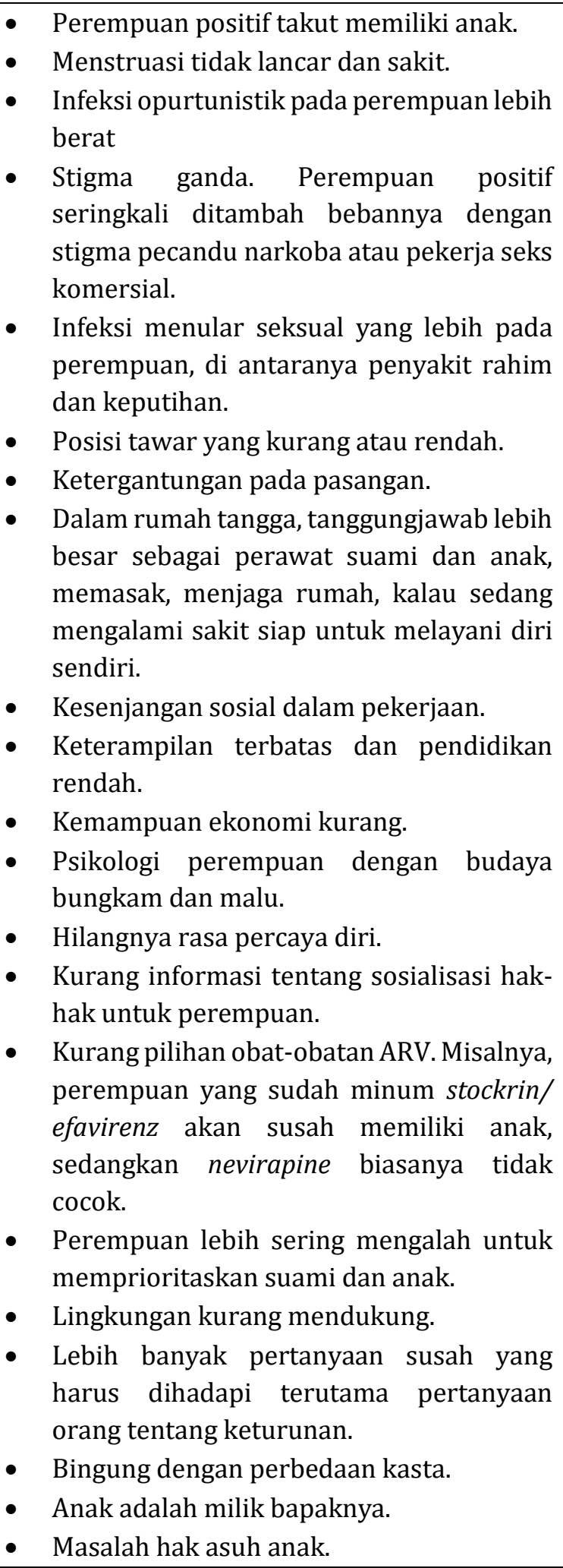 & 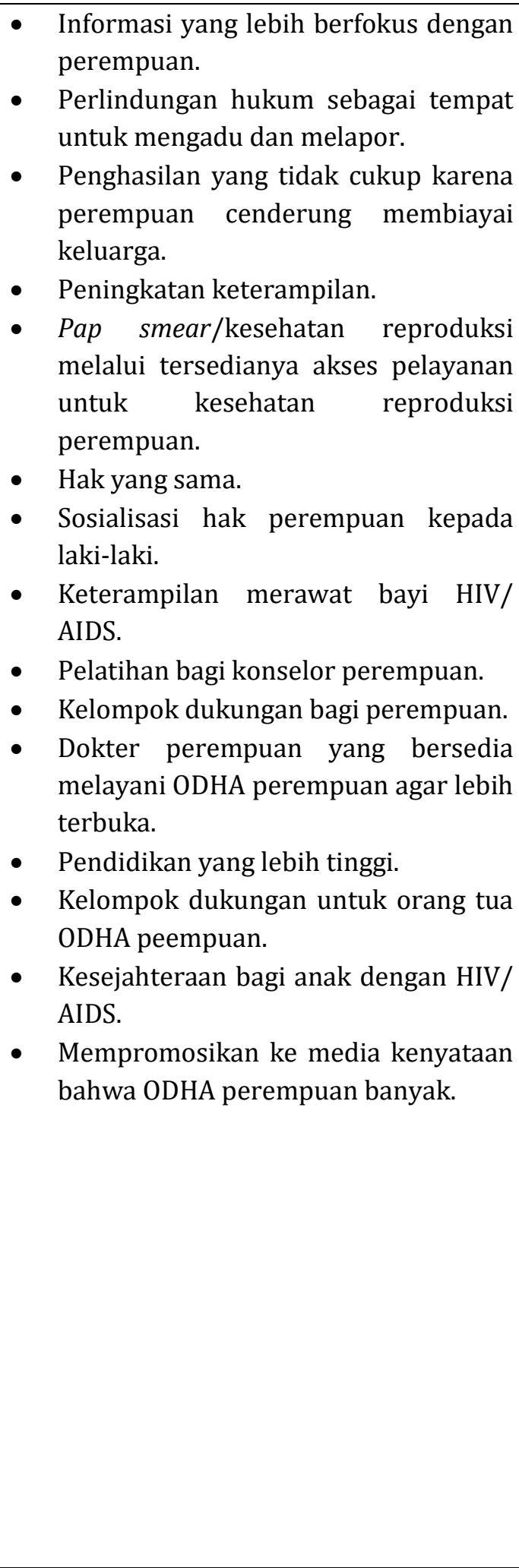 \\
\hline
\end{tabular}


Khazanah Theologia, Vol. 3 No. 3 (2021): 147-160

Biarkanlah Perempuan dengan HIV/AIDS Berbicara! Teologi Interkultural Feminis Poskolonial dalam

Ketidakadilan Gender

Paulus Eko Kristianto

Di sisi lain, perempuan positif turut memperoleh stigma sebagai "perempuan nakal" sehingga ia dimungkinkan menjadi subaltern. Padahal, penularan HIV/AIDS bukan sepenuhnya sebagai dampak dari aktivitas seks komersial. Pekerja seks komersial memang bisa dikategorikan sebagai kelompok resiko tinggi terinfeksi HIV/AIDS. Namun, kita juga harus sadar bahwa penularan HIV/AIDS tidak hanya melalui aktivitas seksual, melainkan penggunaan jarum suntik, dan transfusi darah. Oleh karenanya, semua kelompok masyarakat berpeluang mengalami HIV/AIDS. Perempuan positif harus tetap diupayakan memiliki harapan kehidupan melalui berbagai kebutuhan sebagaimana diuraikan pada tabel 1.

Perempuan dimungkinkan menanggung beban ganda bila ada salah satu anggota keluarganya terkena HIV/AIDS. Sebab, jika yang terkena HIV yakni kepala keluarga laki-laki, maka istrinyalah yang akan memberikan perawatan dan mengambil alih tugas untuk mendukung keluarganya. Dan sama halnya, jika ibu terinfeksi HIV/AIDS dari ayahnya, maka anak perempuannyalah yang harus merawat buah hati mereka yang sakit. Perempuan dan anak-anak dapat terjerumus ke dalam eksploitasi seksual sebagai akibat dari hilangnya pendapatan dari laki-laki sebagai kepala keluarga.

Beban tersebut bisa bertambah banyak apabila perempuan itu ternyata juga seorang pecandu narkoba, atau memiliki anggota keluarga pecandu. Situasi ini bisa distigma oleh masyarakat. Sebab, masyarakat masih menganggap bahwa jika seorang perempuan menjadi pecandu, maka ibu bisa disalahkan dan dianggap tidak beres dalam mengurus anaknya. Padahal sebagaimana kita ketahui, minim sekali orang tua manapun yang menginginkan anaknya menjadi pecandu. Kalaupun ia menjadi pecandu, banyak faktor yang menyebabkannya. Data dari Yayasan Mitra INTI (YMI) dan Sentra Layanan Informasi Drugs, HIV/AIDS dan Reproduksi (SANDAR) menunjukkan perkiraan jumlah pecandu narkoba di Indonesia mencapai 6 juta di mana $30 \%$ di antaranya merupakan pecandu perempuan (INTI \& Drugs, 2005). Bila dilihat dari jumlah, masalah ketergantungan narkoba di Indonesia, terutama di kalangan perempuan sudah merebak luas.

Remaja perempuan kini bisa dikatakan rentan terhadap penggunaan narkoba dan seks. Keduanya berpotensi menjangkitkan HIV/ AIDS (Joyce Djaelani Gordon \& Gordon, 2005). YAKITA dan Yayasan Mitra Inti melalui dukungan Ford Foundation meneliti bahwa tempat pertama kali mencoba narkoba terjadi di Jakarta khususnya area (Joice Djaelani Gordon, Hassan, \& Gordon, 2005):

Tabel 2. Tempat dan Persentase Kemungkinan

\begin{tabular}{cc}
\hline Tempat & Persentase \\
\hline Tempat Kos & $5 \%$ \\
\hline Rumah Teman & $5 \%$ \\
\hline Diskotik & $11 \%$ \\
\hline Rumah & $11 \%$ \\
\hline Sekolah/ Kampus & $47 \%$ \\
\hline Tempat Nongkrong & $21 \%$ \\
\hline
\end{tabular}

Berdasarkan tabel 2, kita bisa melihat bahwa diskotik ternyata tidak lebih berbahaya dibanding sekolah atau kampus. Orang tua bisa merasa aman secara semu karena anaknya pergi ke sekolah atau kampus. Padahal, tanpa orang tua ketahui bahwa anak sangat terbuka pada kemungkinan menyalahgunakan narkoba. Hal lain yang perlu dicatat orang tua yakni remaja perempuan umumnya memperoleh narkoba pertama kali dari pacar dan teman laki-lakinya. Mewaspadai teman laki-laki anak perempuannya menjadi sangat penting. Namun dalam hal ini, waspada, tentu bukan untuk diartikan sebagai pengekangan. Kepedulian yang tinggi pada teman laki-laki atau pacar membuat remaja berusaha 
Khazanah Theologia, Vol. 3 No. 3 (2021): 147-160

Biarkanlah Perempuan dengan HIV/AIDS Berbicara! Teologi Interkultural Feminis Poskolonial dalam Ketidakadilan Gender

Paulus Eko Kristianto

keras menjadi penyelamat orang yang terkena narkoba hingga jenjang pernikahan. Sebagai contoh, hal ini dapat diperhatikan pada cerita berikut (Joyce Djaelani Gordon \& Gordon, 2005):

Waktu saya berkenalan dengan suami saya, saya tidak pernah memakai narkoba. Setelah menikah, saya capek menyuruhnya berhenti menggunakan putaw. Lalu saya mengancam, kalau dia tidak berhenti juga, maka saya akan ikut pakai. Lalu, saya mulai pakai, walaupun hamil. Suami saya tidak menghentikan saya. Ia bahkan menyuntikkan putaw untuk saya. Saya kecanduan. Kehidupan kami menjadi anjlok sesudah itu. Saya kehilangan bayi kamu karena terus menggunakan putaw dan terinfeksi Hepatitis C dan HIV. Saya yakin saya mendapatkan kedua macam virus itu dari suami saya. (Kisah pengalaman dari Lanny, 28 tahun perempuan dan pecandu).

Berdasarkan kisah tersebut, Lanny terkena narkoba dan HIV/ AIDS dari pasangannya. Bisa dikatakan, ia awalnya anak manis yang peduli terhadap orang lain. Namun, kepedulian pada orang lain justru membuat ia terjatuh. Lanny menuntut janji yang tidak ditepati suaminya membuatnya akhirnya ikut memakai narkoba suaminya. Kebingungan Lanny akan makna cinta dan kesulitannya mengatakan tidak dan meninggalkan pacar yang bermasalah membuatnya tidak berkutik ketika diajak menikah. Dengan kata lain, Lanny bisa disebut sebagai perempuan Kodependen. Joyce dan David memetakan perempuan kodependen berciri cenderung diam saja untuk menghindari argumentasi, khawatir akan apa yang dipikirkan orang tentang dirinya, hidup serumah dengan orang yang mengecilkan dan menyakiti dirinya, dan senantiasa bingung siapa dirinya sebenarnya dan kemana arah hidupnya sesungguhnya (Joyce Djaelani Gordon \& Gordon, 2005).

Ketimpangan gender menyebabkan perempuan sulit memperoleh pengetahuan dan informasi berkenaan kesehatan reproduksi, termasuk HIV/ AIDS. Dengan kata lain, hal ini bisa dikatakan berkenaan dengan aksesibilitas. Pelanggaran terhadap hak untuk memperoleh pengetahuan berhubungan langsung dengan asumsi kultural mengenai siapa yang terbaik menentukan pertimbangan. Bagaimanapun, kurangnya partisipasi perempuan dalam pengambilan keputusan bisa makin memperburuk kehidupan mereka. Dengan demikian, endemik HIV/ AIDS telah menimbulkan pelanggaran terhadap Hak Asasi Manusia. Perempuan telah dilanggar haknya dalam kesehatan, terutama untuk mengakses pelayanan kesehatan yang lebih baik, akses terhadap pendidikan dan informasi, dan kemandirian ekonomi. Perempuan yang terinfeksi HIV mengalami pelanggaran hak asasi lebih lanjut melalui perampasan hak merawat anak dan kebebasan dalam reproduksi. Hal ini dikarenakan hak kerahasiaan status HIV perempuan telah ditelanjangi.

\section{Belajar dari Gayatri Chakravorty Spivak: Perempuan Membebaskan Diri dan Berbicara}

Berpijak pada situasi di atas, kita bisa mengatakan bahwa perempuan sedang mengalami kolonialisasi. Kolonialisasi membuat mereka tidak mampu berjuang untuk bertahan hidup menghadapi HIV/ AIDS. Masalahnya, apakah hal tersebut harus terjadi demikian? Penulis merasa perempuan harus bangkit dan berjuang mengatasi kolonialisasi. Kebangkitan perempuan dapat teraktual apabila ia memiliki semangat dan budaya mendukungnya. Dalam hal ini, penulis mengajukan pemikiran Gayatri Chakravorty Spivak sebagai pijakan dan pisau analisis. Penulis menyadari bahwa Spivak memang tidak membahas perempuan dan endemik HIV/ AIDS secara khusus, tetapi kita bisa belajar nilai-nilai dan semangat juangnya dalam menghadapi kolonialisasi. Sikap dan semangat ini biasa disebut poskolonial.

Spivak bisa dikatakan sebagai tokoh perempuan dalam membangun kajian poskolonial. Sebab, ia banyak berbicara seputar warisan filosofis, kultural, politis, dan ekonomis kolonialisme Eropa pada masyarakat jajahan mereka. Walau demikian, Stephen Morton mengatakan bahwa 
Khazanah Theologia, Vol. 3 No. 3 (2021): 147-160

Biarkanlah Perempuan dengan HIV/AIDS Berbicara! Teologi Interkultural Feminis Poskolonial dalam Ketidakadilan Gender

Paulus Eko Kristianto

Spivak cenderung menolak label poskolonial pada dirinya. Sebab, teori poskolonial terlalu terfokus pada bentuk masa lalu dominasi kolonial dan karenanya tidak sesuai untuk mengkritik pengaruh dominasi ekonomi global dan kebijakan struktur International Monetary Fund (IMF) serta terhadap perekonomian dan masyarakat dunia selatan (Morton, 2008). Bagi penulis, penolakan Spivak atas label poskolonial pada dirinya dapat dilihat sebagai ajakan untuk belajar pemikiran Spivak secara utuh dan menyeluruh dengan melintasi disiplin ilmu "resmi", seperti antropologi, sejarah, filsafat, kritik sastra, sosiologi yang mengaburkan batas dan mengembangkan penggabungan metodologi kontemporer antara marxisme, feminisme, dan dekonstruksi sehingga tidak terjebak pada satu sisi poskolonial saja. Tapi, hal ini bukan berarti bahwa Spivak tidak bisa diperhitungkan sebagai tokoh poskolonial.

Bagi Spivak, kajian poskolonial bisa dikatakan sebagai bentuk penalaran. Sebab, ia menawarkan bahwa poskolonial merupakan sistem pemikiran rasional dan koheren dengan analog atas tradisi filsafat Barat. Morton mencatat penalaran poskolonial Spivak didukung oleh upaya Spivak yang menyinggung ide Kant sebagai upaya sistematis untuk mendemonstrasikan berbagai batas penalaran yang telah ditetapkan dan dipandang penting atas berbagai pembahasan kritis berbagai prinsip universalnya (Morton, 2008). Bila dilihat lebih jauh, Spivak menggunakan label tersebut berangkat dari pertimbangan. Pertimbangan itu menjelaskan bahwa apabila terdapat rasionalitas atau penalaran yang mendukung kajian poskolonial, maka ia tidak bisa dipisahkan atas warisan pengetahuan dan kekuasaan kolonial Barat. Oleh karenanya, semua warisan pengetahuan itu perlu dipandang secara kritis.

Penalaran poskolonial berjalan dengan orientasi subaltern. Bagi Spivak, subaltern tidak hanya berkenaan pada kaum perempuan, melainkan berbagai kelompok marginal. Kelompok marginal kerap dipandang sebagai obyek dari kelas dominan dan berkuasa. Kondisi tersebut membuat mereka tidak mampu berbicara guna membela dirinya sendiri. Oleh karenanya, Spivak mencoba memantik budaya berbicara mereka melalui uraiannya dalam "Can the Subaltern Speak?". Spivak melihat subaltern cenderung sulit berbicara dikarenakan mereka senantiasa berhadapan dengan hambatan adanya ketergantungan terhadap intelektual dan cara berpikir Barat (Morton, 2008). Kalaupun mereka berbicara, suaranya dimungkinkan lebih menunjukkan suara dan kepentingan Barat. Spivak merasa subaltern harus belajar berani berbicara atas kondisinya sendiri. Hal ini dilakukan melalui berbagai kritik secara terus-menerus terhadap berbagai wacana yang sudah dirancang telah membungkam berbagai suara subaltern.

Istilah "subaltern" diadopsi dari pemikir Italia, Antonio Gramsci" yang menggunakannya bagi kelompok sosial subordinat. Hal itu terjadi dalam konteks di mana para pekerja dan petani yang tertindas dan didiskriminasi oleh pemimpin Partai Fasis Nasional bernama Benito Mussolini (Louai, 2005). Kemudian dalam uraiannya, Spivak menjelaskan sejarawan India, Ranajit Guha, dari kelompok kajian subaltern mengadopsi gagasan Gramsci guna mendorong penulisan kembali sejarah India yang berikutnya mendefinisikan subaltern sebagai "mereka yang bukan elite" (Louai, 2005). Gagasan Guha turut menggeser dikotomi "menindas-ditindas" karena penindasan juga dilakukan oleh orang-orang dalam kelompok. Artikel "Can the Subaltern Speak?" merupakan penegasan penemuan Guha. Dalam penyajiannya, Spivak menggunakan cerita Bhuvaneswari Bhaduri. Bhuvaneswari Bhaduri merupakan adik neneknya yang berusia sekitar 16-17 tahun. Ia melakukan bunuh diri dengan cara menggantungkan diri di apartemen ayahnya yang sederhana di Calcutta Utara pada tahun 1926. Peristiwa bunuh diri tersebut mengandung teka-teki sehingga menimbulkan desas-desus bahwa ia telah hamil di luar nikah, tetapi belakangan dugaan tersebut 
Khazanah Theologia, Vol. 3 No. 3 (2021): 147-160

Biarkanlah Perempuan dengan HIV/AIDS Berbicara! Teologi Interkultural Feminis Poskolonial dalam Ketidakadilan Gender

Paulus Eko Kristianto

tidak benar karena ia baru selesai menstruasi ketika gantung diri. Hampir sepuluh tahun kemudian, baru diketahui bahwa ia ternyata merupakan salah satu anggota kelompok yang terlibat dalam perjuangan bersenjata bagi kemerdekaan India. Keputusan gantung diri diambil karena ia tak mampu melakukan pembunuhan politik yang dipercayakan kelompok itu kepadanya sehingga ia mengalami penindasan.

\section{Menelisik Teologi Feminis Poskolonial}

Teologi feminis poskolonial bisa dibilang sebagai arus baru dalam teologi Asia. Teologi ini meminjam beragam istilah dalam kajian feminis dan poskolonial. Berbagai uraian poskolonial setidaknya dapat diperhatikan pada bagian sebelumnya. Poskolonialisme memberi tekanan pada membebaskan subaltern dari sistem atau struktur yang membelenggunya. Spivak menunjukkan langkah itu dilakukan melalui memfasilitasi mereka berbicara. Dari gagasan tersebut, R.S. Sugirtharajah melihat poskolonialisme sebagai pembacaan yang memiliki sifat perlawanan, dan gugatan terhadap dominasi pemikiran dan penciptaan makna yang berpusat pada imperialis, ideologi penguasa dan inkarnasi yang berkelanjutan dalam kajian politik, ekonomi, sejarah, teologi, dan kitab suci (Morton, 2008). Dominasi tersebut dibongkar secara kritis.

Kwok Pui-Lan menunjukkan teologi feminis poskolonial berangkat dari pemahaman membongkar teolog yang menganut norma eurosentris, kelas menengah, dan kulit putih yang terlebih dahulu menulis teologi. Oleh karenanya, teolog feminis poskolonial memiliki pekerjaan rumah untuk mendefinisikan horizon teori, materi, dan masa depannya. Teologi feminis poskolonial melawan sejarah dan teologi yang meminggirkan, bahkan menyingkirkan perempuan Kristen. Kwok Pui-Lan memulai teologi feminis poskolonial dengan melukis ulang identitasnya sebagai perempuan Kristen Cina yang kerap menjadi subaltern. Pui-Lan bersama perempuan Kristen Cina lainnya hidup di tepian sejarah dan gereja. Meskipun demikian, Pui-Lan melihat tepian sebagai titik berangkat ideal dalam berteologi feminis poskolonial. Secara detail, hal tersebut diungkapkannya berikut (Pui-Lan, 2001):

Aku penyair Allah feminis Asia yang berteologi dari tepian. Sebagai warga Hongkong, aku juga hidup di tepian karena Hong Kong sebagai Mutiara Timur, merupakan ruang dan waktu pinjaman. Aku lahir sebagai orang China, namun hidup di bawah rezim Inggris. Aku bergabung dalam komunitas Kristen Asia, tetapi menjadi liyan dalam geopolitik gereja. Aku bagian dari mayoritas perempuan Kristen yang disumpal mulutnya di gereja. Aku penyair Allah feminis Cina.

Para teolog poskolonial makin menggunakan sisi tepian. Jung Young Lee menggunakan tepian (marginality) sebagai kunci dalam menyusun teologi antarbudaya. Lee melihat tepian dan pusat sebagai posisi setara. Artinya, keberadaan pusat mengandaikan tepian dan sebaliknya ketika menyebut tepian, pada saat bersamaan kita mengakui keberadaan pusat. Sebagian besar masyarakat cenderung melihat realitas dari perspektif pusat dan mengabaikan kutub tepian. Oleh karenanya, Lee dengan sadar menekankan perspektif tepian karena hendak mengembalikan pusat otentik yang liberatif. Perspektif pusat menciptakan penindasan karena berdasarkan pada nilai hierarkis, sedangkan perspektif tepian menciptakan pembebasan karena memegang prinsip kesetaraan (Lee, 1995).

Kembali pada uraian Pui-Lan, ia melihat perempuan Kristen Cina sebagai subyek diasporik. Mereka sering mengalami dislokasi dan sekaligus relokasi karena berulang-ulang menyeberangi garis batas. Wacana diasporik dalam kajian poskolonial telah menggugat konstruksi tradisional 
Khazanah Theologia, Vol. 3 No. 3 (2021): 147-160

Biarkanlah Perempuan dengan HIV/AIDS Berbicara! Teologi Interkultural Feminis Poskolonial dalam Ketidakadilan Gender

Paulus Eko Kristianto

pusat dan pinggiran. Akademisi poskolonial menangkap adanya gerakan dinamis menjauhi pusat dan kemajemukannya. Hal tersebut turut berimbas pada perempuan sebagai subyek diasporik juga. Mereka bernegosiasi dengan masa lalu yang ambivalen, dan pada saat yang sama berpegang pada fragmen kenangan, budaya, dan sejarah demi masa depan yang berbeda. Oleh karenannya, Pui-Lan menilik kehidupan perempuan Kristen Cina di dalam gereja yang mengebawahkan perempuan, serta tanggapan mereka terhadap kitab suci dan ibadah. Ia tertarik melihat peran perempuan dalam gereja dan masyarakat ketika Cina mengalami semi-kolonialisasi.

Melalui uraian di atas, kita perlu menggarisbawahi bahwa para teolog feminis poskolonial telah mengajukan sumber-sumber baru dari pengalaman perempuan. Mereka mencari titik solidaritas yang mempertemukan keberagaman pengalaman perempuan. Pui-lan menegaskan keberagaman suara tersebut telah menciptakan atmosfer yang saling kritik guna memperkaya subyek dalam wacana (Pui-Lan, 2005). Para teolog feminis poskolonial juga menolak gambaran romantik mengenai perempuan sebagai ciptaan yang lebih memperhatikan dan mengasihi ciptaan lain, serta memiliki relasi yang lebih dekat dengan Allah. Sebab, kajian studi gay, lesbian, lelakiperempuan, dan biseksual membantu teologi feminis poskolonial untuk mengguncang-guncang konstruksi gender dikotomik yang melihat perempuan sebagai ciptaan baik dan laki-laki sebaliknya.

\section{Berteologi (Misi) Interkultural}

Sebelum kita meramu teologi (misi) interkultural poskolonial, penulis menyajikan terlebih dahulu bingkai teologi interkultural. Dari mana istilah "interkultural" muncul? Sejak abad ke-15 hingga pertengahan abad ke-20, para misionaris Barat telah mengelilingi dunia guna "mengkristenkan" penduduk asli bersama kolonialisasi. Lambat laun, mereka juga mulai menghargai kebudayaan lain. Hal tersebut memuncak pada perasaan "malu" pada keterikatan misi dan kolonialisme. Maka, kata "misi" diganti dunia Barat dengan "teologi interkultural". Secara sederhana, mereka mendefinisikan teologi ini sebagai upaya pertemuan atau interaksi global dan lokal antar agama, denominasi atau aliran agama, dan kebudayaan. Melalui pendefinisian tersebut, teologi interkultural berkembang berdasarkan kesadaran bahwa tidak ada lagi teologi universal, melainkan sudah melebur dalam konteks dan kebudayaan setempat. Maka, interaksi dan komunikasi antar budaya, agama, denominasi, dan aliran-aliran agama menjadi sangat dibutuhkan.

Teologi interkultural dirintis oleh Walter Hollenweger, Hans Jochen Margull, dan Richard Friedli. Friedli mencoba memetakan tiga prinsip utama teologi interkultural sebagai berikut (Friedli, 1987) (Jong, 2015); [1] Teologi interkultural merupakan disiplin ilmiah tentang Firman Allah dan penawaran keselamatan-Nya, yang beroperasi dalam jangkauan suatu kebudayaan tertentu. Namun tanpa memutlakkan disiplin tersebut, teologi Tubuh Kristus yang sakramental direfleksikan dalam rangka kebudayaan. [2] Metode teologi interkultural tergantung pada konteks. Hal ini tidak berarti, bahwa teologi Eropa sama sekali tidak bermanfaat lagi, tetapi tidak boleh dimutlakkan juga. Teologi interkultural merupakan teologi kontekstual. [3] Metode penelitian dan modeljemaat dari ilmu teologi Barat dapat dan harus diperkaya oleh susunan teologis alternatif. [4] Teologi interkultural tidak dapat dilepaskan seluruhnya dari metode ilmu rasional-kritis yang berkembang di dalam kebudayaan Barat. Namun, teologi interkultural juga menuntut proses penyaringan kritis atas metode tersebut yang diterapkan pada seluruh proses komunikasi antar budaya, denominasi gereja, dan agama.

Melalui uraian Friedli, kita bisa mengetahui bahwa masalah "kelainan" (otherness) menjadi penting bagi masa depan kekristenan dan agama-agama lain. Franz Xaver Scheuerer menunjukkan muka dari 
Khazanah Theologia, Vol. 3 No. 3 (2021): 147-160

Biarkanlah Perempuan dengan HIV/AIDS Berbicara! Teologi Interkultural Feminis Poskolonial dalam Ketidakadilan Gender

Paulus Eko Kristianto

yang lain memberi suatu sumbangan bagi interkultural. Mengapa demikian? Menurut Scheuerer, pemikiran Emmanuel Levinas merupakan suatu peringatan penting di mana "yang lain" memungkinkan para teolog saling belajar dari yang lain, mengucapkan pendapat berbeda, dan menawarkan pengertian yang belum diketahui yang lain (Scheuerer, 2001) (Jong, 2015). Pertemuan dengan "yang lain" berarti bertemu dengan seorang asing. Artinya, jika ada beda budaya, tidak mungkin untuk langsung mengerti orang lain. Oleh karenanya, Friedli menegaskannya jika orang bertemu dengan orang lain, mereka sekaligus juga bertemu dengan orang lain. Bahkan, mereka sekaligus bertemu dengan keasingan karena mungkin budaya, suku, agama, denominasi, aliran agama, atau keyakinan orang lain menjadi asing bagi orang lain. Dengan demikian, dalam pertemuan selalu ada unsur asing, lain, yang tidak langsung bisa dimengerti, dan mungkin belum pernah bisa dimengerti sepenuhnya.

Bila kita menilik asal usul istilah "interkultural" sendiri, maka ia berasal dari ilmu komunikasi. Dalam ilmu komunikasi, keberbagaian budaya tidak sekedar diterima sebagai fakta, namun ditanggapi dengan berbagai tawaran strategi dan metodologi agar komunikasi antarbudaya dapat berlangsung degan lancer dan mencapai hasil yang diinginkan. Maka, teolog tidak cukup hanya menyadari saja keragaman budaya dari masyarakat di mana ia berada, namun belajar cara berkomunikasi yang tepat sebagai siasat untuk hidup bersama dengan baik. Tapi, teologi interkultural tidak mencukupkan diri pada komunikasi antarbudaya, melainkan membawa hasil komunikasi atau perjumpaan antarbudaya tersebut dalam refleksi teologis. Teolog mencoba mengajukan pertanyaan pokok terkait apa yang sebenarnya dicari oleh budaya-budaya manusia. Teologi interkultural mencari sesuatu dibalik berbagai kebudayaan yang ada (Cheetam, 2011) (Setio, 2008).

Dalam berteologi interkultural, kita perlu bertransformasi dengan mengajukan pertanyaan. Berteologi harus selalu bertanya. Ketika sebuah pertanyaan sudah nampak bisa dijawab, teologi masih datang dengan pertanyaan sambungannya sehingga semua membentuk rangkaian pertanyaan-jawabanpertanyaan-jawaban, dan kembali lagi ke pertanyaan lalu ke jawaban dan seterusnya. Graham Ward memakai sebutan "pemuridan" untuk kondisi yang tidak pernah berakhir itu. Ward menjelaskan sebagai murid Kristus, kita tidak boleh berpuas diri dengan apa yang sudah ditemukan (Ward, 2020) (Setio, 2008). Kita perlu terus belajar dengan mengandaikan belum diketahuinya sesuatu yang ingin dipelajari. Belajar demikian membuat kita senantiasa mengalami transformasi diri seiring proses belajar yang tidak pernah selesai.

Dengan memakai pemahaman lain dari Jacques Derrida, kita bisa mengatakan bahwa tidak ada sebuah pengetahuan yang tak bisa didekonstruksi. Pengetahuan bersifat eliptikal, berputar ke arah awal di mana asumsi berada sekalipun bisa diungkapkan. Dekonstruksi tidak boleh dipandang negatif. Dengan melakukan dekonstruksi, kita mencerahkan diri kita sendiri. Kita menjadi sadar akan keterbatasan kita. Ketika kesadaran akan kelemahan muncul, kemauan untuk berubah juga akan muncul. Teologi yang bertanya menjalankan fungsi pemuridan dan dekonstruksi. Teologi demikian mengingatkan bagaimana kita di hadapan Tuhan. Sebab, pengetahuan sebaik dan sebesar apapun yang kita miliki tentang dan dari Tuhan, kita tetap ringkih karena kemanusiaan dan keterbatasan. Keringkihan bukanlah alasan bagi kita untuk berhenti berteologi karena keadaan apapun yang kita kehendaki atau pilih tetap juga rentan terhadap kelemahan dan tuntutan perubahan.

\section{Berteologi (Misi) Interkultural Feminis Poskolonial dalam Konteks Ketidakadilan Gender}

Setelah kita melihat uraian fondasi di atas, bagaimana model berteologi (misi) interkultural feminis poskolonial dalam konteks ketidakadilan gender yang dialami perempuan pengidap HIV/ AIDS? Secara 
Khazanah Theologia, Vol. 3 No. 3 (2021): 147-160

Biarkanlah Perempuan dengan HIV/AIDS Berbicara! Teologi Interkultural Feminis Poskolonial dalam Ketidakadilan Gender

Paulus Eko Kristianto

cepat, kita bisa mengatakan teologi interkultural feminis poskolonial perlu menyuarakan keberadaan mereka sebagai subaltern. Hal itu dilakukan agar mereka mereka mengalami keadilan gender. Hal itu ada benarnya. Masalahnya, bagaimana caranya? Penulis mengingatkan bahwa pemahaman teologi interkultural tidak melulu berkutat pada ritual semata, melainkan berdialog dengan konteks, kemudian mencoba mengatasi satu per satu persoalan yang ada. Secara singkat, penulis mengusulkan lima poin yang perlu diperhatikan dalam berteologi (misi) interkultural feminis poskolonialberkenaan kasus ini.

Lima poin tersebut yakni; [1] Kita perlu menempatkan kerentanan perempuan terhadap HIV dalam konteks posisi strukturalnya dalam masyarakat. [2] Pendekatan penanggulangan HIV tidak bisa dipisahkan dari peningkatan kapasitas perempuan dalam perlindungan hak-haknya. [3] Kita perlu menyadari bahwa perempuan tidak bisa dipukul rata karena konteks spesifik seorang perempuan dari Suku Auyu di Merauke tidak akan sama dengan kebutuhan seorang buruh perempuan yang bekerja di industri garmen di Cileungsi. [4] Kita perlu membangun dan menciptakan alat analisis untuk mengembangkan sebuah program yang berdimensi penguatan dan perlindungan hak-hak perempuan untuk penanggulangan HIV/AIDS. [5] Pendekatan yang terkotak-kotak harus ditinggalkan, kita harus membuka mata untuk melihat perempuan dan laki-laki secara holistik.

Kelima poin tersebut dapat dikembangkan dalam dialog teologi (misi) interkultural profetis. Langkah profetis diharapkan dapat membawa pada pencarian apa yang mungkin dan dapat diubah di dalam dunia, dan misi yang praktis mencakup apa yang kini berada dalam batas-batas kemungkinan di dalam dunia (Thomas, 2009). Perbaikan situasi melekat pada tidak mencari tatanan-tatanan kekal dalam realita dunia yang semakin melanggengkan praktik yang kurang baik mendukung ketidakadilan gender. Misi sebagai dialog profetis memang bukan hal yang mudah. Semangat pengharapan ada perubahan harus tetap ada mengiring strategi tersebut. Pengharapan yang bukan semata mengarah pada masa depan melainkan masa kini dan di sini.

David Bosch menggambarkan pengharapan atas pemilikan dan pada saat yang sama merindukan, ketenangan dan kegiatan, ketibaan dan keberadaan dalam perjalanan (Bosch, 1997). Pengharapan eskatologi dalam dialog profetis sebaiknya tidak membuat kita terperangkap dalam pertanyaan apa yang menjadi rencana Allah untuk masa depan (bahkan masa kini) dunia melainkan mengajak kita merenungkan dan melihat sejauh mana keterlibatan kita dalam dunia. Kita juga perlu mengubah cara pandang kita terkait dunia tidak lagi sebagai penghalang melainkan dunia sebagai tantangan dalam mewujudkan aksi strategi misi yanag mendalam dan kontekstual.

Misi sebagai dialog profetis juga bisa diterapkan melalui berbagai langkah praktis di antaranya: [1]Orang Kristen wajib hidup dalam berbagai cara yang mengajak dan mendorong orang lain untuk mengadopsi gaya hidup yang menggunakan lebih sedikit sumber daya dunia. [2]Setiap orang Kristen dan gereja sebagai institusi dapat mendukung dan menggalakkan perundang-undangan yang meningkatkan keadilan. [3]Gereja dan setiap orang Kristen dapat mendukung dan menggalakkan pengembangan keadilan.Apabila keadilan terwujud, kita bisa berjumpa dengan ciptaan baru. Misi sebagai ciptaan baru mengarahkan perhatian kita kepada masa depan yang kreatif yang dijamin oleh tindakan Allah yang penuh rahmat di masa lampau (Thomas, 2009). Masa depan yang menunjuk pada masa kini yang berlanjut terus dan terdapat sebuah tanpa tujuan melainkan sebagai sebuah proses yang jelas dan berarah ke tujuan. Tujuan akan adanya dunia dan ciptaan baru. Tujuan tersebut dicapai dengan iringan iman. Iman sebagai wujud tanggapan kepada Allah yang memanggil kita untuk bersama Allah sendiri menjadi rekan pencipta langit dan bumi baru sekaligus tantangan untuk melibatkan diri secara konkrit dalam realitas kehidupan dan dunia yang berlangsung. Dunia baru merupakan gambaran realitas komunitas manusia baru yang hidup dalam harmoni luar dalam dengan dirinya sendiri, komunitas, dunia, dan Allah. 
Khazanah Theologia, Vol. 3 No. 3 (2021): 147-160

Biarkanlah Perempuan dengan HIV/AIDS Berbicara! Teologi Interkultural Feminis Poskolonial dalam Ketidakadilan Gender

Paulus Eko Kristianto

\section{Implikasinya dalam Pelayanan Gereja Antargenerasi}

Setelah memperhatikan uraian teologi (misi) interkultural tersebut, lantas bagaimana mengimplementasikannya dalam pelayanan gereja antargenerasi? Sebelum menjawab pertanyaan tersebut, pembaca perlu memperhatikan hakikat dari pelayanan. Di lingkungan gereja, kata "pelayanan" bisa dibilang paling banyak dipakai di samping kata "mengasihi". Pada umumnya, pelayanan dimaknai melayani Tuhan. Kemudian, hal itu dijabarkan dalam kegiatan ibadah, kebaktian, dan doa. Masalahnya, apakah memang demikian? Tentu tidak. Pelayanan tidak melulu seputar pada Tuhan, melainkan melayani sesama secara konkrit. Oleh karenanya, pelayanan gereja biasa diletakkan dalam bingkai "tridarma" gereja secara umum yang merujuk pada persekutuan (koinonia), pelayanan (diakonia), dan kesaksian (marturia). E. Gerrit Singgih menegaskan ketiga tridarma tersebut tidak dimaksudkan berpisah-pisah dalam praktik, melainkan sinergis (Singgih, 1997). Artinya, marturia bisa bersifat ritual, tetapi juga diakonal, sedangkan koinonia yang bersifat institusional oleh banyak orang malah dianggap ritual. Akibatnya, orang Kristen kerap berbentrokan di antara persekutuandan kesaksian, lalu mengakibatkan pelayanan diakonia terabaikan.Pendek kata, gereja tidak lagi dilihat sebagai persekutuan yang ada sangkut paut dengan masyarakat. Padahal, gereja seharusnya sebagai persekutuan yang disuruh dan berada dalam dunia, meskipun bukan dari dunia.

Berlanjut ke gereja antargenerasi (intergenerational church), bagaimana makna pelayanan di sana? James W. White mendefinisikannya sebagai kumpulan dari dua atau lebih orang-orang yang terdiri dari kategori usia yang berbeda dalam sebuah komunitas religius yang bersama-sama belajar/ bertumbuh/ hidup dalam iman melalui beberapa aspek yakni; pengalaman bersama (in common experiences), pembelajaran paralel (parallel learning), kesempatan untuk memberikan kontribusi (contributive occasion), dan berbagi secara interaktif (interactive sharing) (White, 1988). Melalui definisi di atas, kita bisa melihat bahwa pelayanan dalam gereja antargenerasi tidak terpaku pada kategori usia tertentu yang biasa dilakukan gereja. Namun, pelayanan demikian juga tidak bermaksud meniadakan pelayanan kategorial melainkan melengkapinya.

Peter Menconi menjelaskan pelayanan antargenerasi didasari sembilan pertimbangan (Menconi, 2010). [1] Semua generasi berharga di mata Tuhan. [2] Kita perlu menghormati dan menghargai jasa generasi terdahulu. [3] Kita perlu mengajarkan dan mengenalkan Kristus bagi generasi masa depan. [4] Gereja antargenerasi yang sehat merupakan saksi bagi masyarakat sekitar. [5] Kita perlu memahami generasi sekarang dan semua dinamikanya agar kita bisa saling belajar dan sebaliknya. [6] Gereja antargenerasi menyiapkan para pemimpin masa depan yang bisa dikembangkan lebih maksimal. [7] Gereja perlu menanggapi berbagai perubahan yang ada.[8] Semua generasi memiliki kesempatan yang sama untuk memberikan persembahan kepada Tuhan. [9] Semua generasi perlu bersatu sebagai tubuh Kristus dalam karya dan pelayanan.

Pelayanan (gereja)antargenerasi dikemas dengan adanya pengharapan bahwa semua jemaat merupakan satu tubuh dalam Kristus. Kristus sebagai kepala gereja dan jemaat sebagai anggota tubuhnya. Tubuh harus berlaku kooperatif satu sama lain (Menconi, 2010). Pemahaman demikian juga berlaku bagi semua generasi. Sebagai tubuh Kristus, semua generasi memiliki nilai-nilai masing-masing untuk dibagikan guna membangun iman. Setelah kita mengetahui pemahaman dasar pelayanan gereja antargenerasi, kita kembali ke pertanyaan utama mengenai implikasi teologi (misi) interkultural dalam pelayanan demikian.

Persoalan ketidakadilan gender yang dialami perempuan pengidap HIV/ AIDS harus diketahui dan dicari alternatif mengatasinya oleh semua generasi. Bagaimana caranya? Menurut penulis, gereja antargenerasi perlu menyuarakan pemberdayaan dan transformasi sebagai nafas teologi misi poskolonial. 
Khazanah Theologia, Vol. 3 No. 3 (2021): 147-160

Biarkanlah Perempuan dengan HIV/AIDS Berbicara! Teologi Interkultural Feminis Poskolonial dalam Ketidakadilan Gender

Paulus Eko Kristianto

Pemberdayaan perempuan pengidap HIV/ AIDS berfokus pada peningkatan akses informasi, ketrampilan, pelayanan teknologi, dan membangun partisipasi mereka dalam pengambilan keputusan di segala aspek. Pemberdayaan dilakukan untuk membangun citra diri yang positif dan percaya diri, mengembangkan kemampuan berpikir kritis, membangun perpaduan kelompok, berani mengambil keputusan dan melaksanakannya. Dengan kata lain, pemberdayaan diharapkan membuat mereka berani mengambil kendali atas kehidupan mereka, melakukan suatu perubahan, dan mendefinisikan agendanya sendiri.

Pemberdayaan meresap dalam kenyataan hidup yang dialami berbeda-beda oleh masing-masing individu melalui tiga hal yang saling berhubungan yakni identitas, institusi, dan sektor pelayanan. Identitas menyentuh gender, etnisitas, kelas, usia, status HIV, agama, orientasi seksual, dan kebiasaan. Institusi berkenaan keluarga, rekan sebaya, tempat bekerja, komunitas, sekolah, agama, organisasi nonpemerintah, pemerintah, agen bilateral dan multilateral. Kemudian, sektor pelayanan membahas seputar pendidikan, pekerjaan, kesehatan, dan hukum. Ketiga hal tersebut diharapkan menjadi lokus partisipasi sejati. Artinya, pemberdayaan demikian bisa membangkitkan partisipasi dalam menafsir, menganalisa, dan mencari solusi atas semua permasalahan yang ada. Partisipasi dapat dilihat sebagai alat dan sarana untuk mencapai tujuan dengan mengarah pada pengembangan yang lebih efisien.

Pemberdayaan dapat dilihat sebagai tujuan akhir, sekaligus sebagai sarana untuk mencapai transformasi hubungan kekuasaan gender. Artinya, ketika perempuan merasa terberdaya, mereka dapat mengambil tindakan yang dibutuhkan dalam level masyarakat kelompok atau kolektif, dan tingkat masyarakat yang lebih luas dan institusi guna menghadapi, mengatasi, dan mengubah berbagai ketidaksetaraan dalam hubungan kekuasaan gender.Transformasi menjadi hal krusial dalam konteks HIV/ AIDS. Sebab, epidemi HIV/ AIDS berada dalam konteks dinamika kekuasaan yang menindas perempuan serta menambah kerentanan mereka. Transformasi demikian diharapkan dapat mengubah ketidaksetaraan kekuasaan antara laki-laki dan perempuan guna melahirkan keadaan sebaliknya. Pendek kata, transformasi dapat didefinisikan secara lebih luas untuk memasukkan perubahan radikal pada hubungan pribadi, masyarakat, dan tingkat masyarakat, menangani sistem, mekanisme, kebijakan, dan praktik yang dibutuhkan untuk mendukung perubahan. Transformasi relasi gender berfokus pada kesetaraan gender yang terjadi pada tingkat pribadi, organisasi, programatik dan sosial.

Dalam praktiknya, transformasi dilakukan dengan bekerja sama dengan laki-laki. Sebab, apabila kita hanya memusatkan perhatian pada perempuan saja, hal ini dapat menambah beban perempuan pengidap HIV dan berakibat munculnya pandangan bahwa mereka harus disalahkan, contohnya proyek Instituto PROMUNDO. Dalam proyek tersebut, Rio de Janerio Brazil menginisiasikan sebuah proyek yang melibatkan pemuda muda guna menanggulangi kekerasan berbasis gender. Hal itu dilakukan karena sikap dan perilaku kekerasan terhadap perempuan terbentuk sejak remaja. Proyek ini dimulai dengan mencari pemuda yang menentang perilaku kekerasan berbasis gender guna direkrut sebagai fasilitator. Sebelum mereka terjun, para fasilitator senior memberikan pengarahan dan bekal wawasan keadilan gender.

\section{SIMPULAN}

Di lingkungan gereja, kata "pelayanan" bisa dibilang paling banyak dipakai di samping kata "mengasihi". Pada umumnya, pelayanan dimaknai melayani Tuhan. Kemudian, hal itu dijabarkan dalam kegiatan ibadah, kebaktian, dan doa. Masalahnya, apakah memang demikian? Tentu tidak. Pelayanan tidak melulu seputar pada Tuhan, melainkan melayani sesama secara konkrit, termasuk mewujudkan keadilan gender bagi perempuan pengidap HIV/AIDS. 
Khazanah Theologia, Vol. 3 No. 3 (2021): 147-160

Biarkanlah Perempuan dengan HIV/AIDS Berbicara! Teologi Interkultural Feminis Poskolonial dalam Ketidakadilan Gender

Paulus Eko Kristianto

\section{REFERENSI}

Arifin, N. (2005). Membuka Mata Masyarakat: Menghapus Diskriminasi dan Stigma Perempuan dengan HIV/ AIDS. Jurnal Perempuan, 43.

Awaworyi Churchill, S., Appau, S., \& Ocloo, J. E. (2021). Religion and the Risks of Sexually Transmissible Infections: Evidence from Britain. Journal of Religion and Health, 60(3), 1613-1629. https://doi.org/10.1007/s10943-021-01239-0

Bosch, D. J. (1997). Transformasi Misi Kristen: Sejarah Teologi Misi yang Mengubah dan Berubah. Jakarta: BPK Gunung Mulia.

Cheetam, D. (2011). Intercultural Theology and Interreligious Studies. In M. J. Carledge \& D. Cheetam (Eds.), Intercultural Theology (p. 215). London: SCM Press.

Friedli, R. (1987). Interkulturelle Theology. In K. Muller \& T. Sundermeier (Eds.), Lexicon MissionsTheologischer Grundbegriffe (pp. 183-184). Berlin: Dietrich Reimer Verlag.

Gordon, Joice Djaelani, Hassan, A. P., \& Gordon, D. D. (2005). Perempuan di Balik Tirai Dunia Narkoba. Jakarta: Ford Foundation YAKITA dan Yayasan Mitra Inti.

Gordon, Joyce Djaelani, \& Gordon, D. D. (2005). Membentengi Perempuan dan Anak dari Narkoba dan HIV/ AIDS: Memahami Peran Keluarga dan Lingkungan. Jurnal Perempuan, 43.

INTI, Y. M., \& Drugs, S. L. I. (2005). HIV/ AIDS dan Reproduksi (SANDAR) Seri Factsheet HIV/ AIDS 1 No. 3 Februari.

Jong, K. de. (2015). Teologi (Misi) Interkultural. In K. de Jong \& Y. Tridarmanto (Eds.), Teologi dalam Silang Budaya: Menguak Makna Teologi Interkultural serta Perannya bagi Upaya Berolah Teologi di Tengah-tengah Pluralisme Masyarakat Indonesia (p. 30). Yogjakarta: UKDW/ TPK.

Lee, J. Y. (1995). Marginality: The Key to Multicultural Theology. Minneapolis: Fortress Press.

Louai, E. H. (2005). Retracing the Concept of the Subaltern from Gramsci to Spivak: Historical Development and New Applications. African Journal of History and Culture, 4.

Mapingure, M., Mukandavire, Z., Chingombe, I., Cuadros, D., Mutenherwa, F., Mugurungi, O., \& Musuka, G. (2021). Understanding HIV and associated risk factors among religious groups in Zimbabwe. BMC Public Health, 21(1), 375. https://doi.org/10.1186/s12889-021-104058

Menconi, P. (2010). The Intergenerational Church: Understanding Congregations from WWII to WWW.COM. Littleton: Mt. Sage Publishing.

Morton, S. (2008). Gayatri Spivak: Etika, Subaltern, dan Kritik Penalaran Poskolonial (terj. Wiwin Indiarti). Yogyakarta: Pararaton.

Ndlovu-Teijema, M. T., Kok, M. O., van Elsland, S. L., Smeets, H., Barstow, D., van Rooyen, L., \& van Furth, A. M. (2021). Setting the global research agenda for community-based HIV service delivery through the faith sector. Health Research Policy and Systems, 19(1), 81. https://doi.org/10.1186/s12961-021-00718-w

Olivier, J., \& Wodon, Q. (2012). The role of faith-inspired health care providers in Sub-Saharan Africa and public-private partnerships: Strengthening the evidence for faith-inspired health engagement in Africa,. Washington: World Bank, Washington, DC.

Pui-Lan, K. (2001). Discovering the Bible in the Non-Biblical World. In Lift Every Voice: Constructing Local Theologies from the Underside (p. 276). Maryknoll: Orbis Books.

Pui-Lan, K. (2005). Postcolonial Imagination and Feminist Theology. Louiseville: John Knox Press.

Scheuerer, F. X. (2001). Interculturality: A Challenge for the Mission of the Church. Bangalore: Asian Trading Corporation.

Setio, R. (2008). Menimbang Posisi Teologi Interkultural. In K. de Jong \& Y. Tridarmanto (Eds.), Teologi dalam Silang Budaya (p. 214).

Singgih, E. G. (1997). Reformasi dan Transformasi Pelayanan Gereja Menyongsong Abad ke-21. Yogjakarta: Kanisius.

Subiyantoro, E. B. (2005). Tentang Perempuan dan HIV/ AIDS Positifnya. Jurnal Perempuan, 43. 
Khazanah Theologia, Vol. 3 No. 3 (2021): 147-160

Biarkanlah Perempuan dengan HIV/AIDS Berbicara! Teologi Interkultural Feminis Poskolonial dalam Ketidakadilan Gender

Paulus Eko Kristianto

Thomas, N. E. (2009). Teks-teks Klasik tentang Misi dan Kekristenan Sedunia. Jakarta: BPK Gunung Mulia.

Ward, G. (2020). Intercultural Theology and Political Discipleship. In M. J. Cartledge \& D. Cheetham (Eds.), Intercultural Theology (p. 56).

White, J. W. (1988). Intergenerational Religious Education. Birmingham: Alabama Religious Education Press.

Ziersch, A., Walsh, M., Baak, M., Rowley, G., Oudih, E., \& Mwanri, L. (2021). "It is not an acceptable disease": A qualitative study of HIV-related stigma and discrimination and impacts on health and wellbeing for people from ethnically diverse backgrounds in Australia. BMC Public Health, 21(1), 779. https://doi.org/10.1186/s12889-021-10679-y 